\title{
Pengaruh Tingkat Percaya Diri CEO terhadap Risiko Penurunan Harga Saham dengan Efisiensi Investasi sebagai Mediasi
}

\author{
Nila Hiliyah Yusuf ${ }^{1}$ \\ Fakultas Ekonomi dan Bisnis \\ Universitas Airlangga, Indonesia
}

Surel : nila.hiliyah.yusuf-2019@feb.unair.ac.id

ABSTRAK

CEO memiliki peranan dalam mengambil keputusan investasi. Usia, pendidikan dan pengalaman kerja menjadi faktor yang dapat mempengaruhi tingkat percaya diri CEO dalam mengambil keputusan. Ketika keputusan investasi yang diambil bersifat bias dan berisiko menurunkan kinerja perusahaan, maka akan ada keputusan CEO untuk menunda informasi buruk. Lamanya penundaan informasi buruk akan meningkatkan risiko menurunnya harga saham di masa depan. Oleh sebab itu tujuan penelitian ini adalah menguji pengaruh tingkat percaya diri CEO terhadap risiko penurunan harga saham di masa depan melalui efisiensi investasi sebagai mediasi. Sektor manufaktur digunakan sebagai objek penelitian dengan 98 perusahaan sebagai sampel penelitian dengan periode penelitian dari tahun 2011-2019. Analisis jalur digunakan sebagai teknik analisis dan sobel test sebagai tolak ukur mediasi. Hasil penelitian ini membuktikan bahwa efisiensi investasi mampu memediasi pengaruh tingkat percaya diri CEO terhadap risiko penurunan harga saham di masa depan.

Kata Kunci: Tingkat Percaya Diri CEO; Efisiensi Investasi; Risiko Penurunan Harga Saham Masa Depan.

\section{The Effect of CEO Confidence Level on Future Stock Price Crash Risk with Investment Efficiency as a Mediator}

\begin{abstract}
$C E O$ has a role to make investment decisions. Age, education and work experience are factors can effect the CEO's confidence level to making decisions. When the investment decisions biased and risk lowering the company's performance, there will be a CEO's decision to delay bad information. Long delays bad information will increase stock price crash risk on future. Therefore, the purpose of this study is to examine the effect of the CEO's confidence level on future stock price crash risk with investment efficiency as a mediation. The manufacturing sector is used as the object of research with 98 companies as research samples with a research period from 2011-2019. Path analysis was used as an analytical technique and Sobel test as a measure of mediation. The results of this study prove that investment efficiency is able to mediate the effect of $C E O$ 's confidence level on future stock price crash risk.
\end{abstract}

Keywords: CEO's Confidence Level; Investment Efficiency; Future Stock Price Decrease Risk.

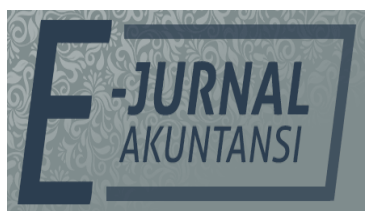

e-ISSN 2302-8556

Vol. 31 No. 10

Denpasar, Oktober 2021

Hal. 2490-2502

DOI:

10.24843/EJA.2021.v31.i10.p07

PENGUTIPAN:

Yusuf, N.H.Y. (2021).

Pengaruh Tingkat Percaya Diri CEO terhadap Risiko Penurunan Harga Saham dengan Efisiensi Investasi sebagai Mediasi. E-Jurnal Akuntansi, 31(10), 2490-2502

RIWAYAT ARTIKEL: Artikel Masuk: 4 Juli 2021 Artikel Diterima: 14 Oktober 2021

Artikel dapat diakses : https://ojs.unud.ac.id/index.php/Akuntansi/index 


\section{PENDAHULUAN}

Laporan keuangan berperan penting bagi perusahaan dalam mengambil keputusan. Menurut Cheng, et al. (2013) dan Gomariz \& Ballesta (2014) laporan keuangan yang berkualitas akan mengarahkan pada ketepatan dalam mengambil keputusan investasi yang efisien. Efisiensi investasi sangat penting bagi riset keuangan perusahaan Ullah, et al., (2020), sebab dalam mendanai investasi tidak hanya dari modal sendiri dan tingkat pendapatan perusahaan tetapi ada dana pihak ketiga seperti hutang bank dan obligasi. Ketika investasi perusahaan di biayai sebagian oleh dana pihak ketiga diharapkan tidak membebani perusahaan yang dapat mengarahkan pada kebangkrutan seperti yang terjadi pada PT Sariwangi Agricultural Estate Agency dan PT Maskapai Perkebunan Indorub Sumber Wadung, dimana dana investasi teknologi yang dikeluarkan tidak sebanding dengan yang dihasilkan.

Sektor manufaktur merupakan salah satu industri yang berhubungan erat dengan pembiayaan R\&D dalam mengembangkan produk baru. Hal tersebut telah diteliti oleh Hur, et al. (2019) yang menjelaskan bahwa menurunnya tingkat penjualan perusahaan tidak mengurangi pembiayaan R\&D perusahaan. Hur, et al. (2019) berpendapat bahwa CEO dengan tingkat percaya diri yang tinggi meyakini bahwa R\&D mewakili biaya dan investasi jangka panjang yang dapat meningkatkan keberlanjutan bisnis di masa mendatang. Tingkat percaya diri CEO yang tinggi dengan berani mengambil risiko diharapkan mampu memberikan dampak positif terhadap kinerja perusahaan, seperti yang dijelaskan oleh Hirshleifer, et al. (2012) dimana CEO yang terlalu percaya diri menjadi sangat antusias dengan perusahaan yang berisiko, menantang, dan memiliki bakat serta peka terhadap visi perusahaan.

Tingginya tingkat percaya diri CEO dalam mengambil keputusan dapat mempengaruhi kinerja perusahaan. Ada perbedaan pendapat antara hasil penelitian terdahulu. Kim, et al. (2016), Lee, et al. (2018), Liang, et al. (2019), dan Mamun, et al. (2020) berpendapat bahwa tingginya tingkat percaya diri CEO mampu untuk meningkatkan risiko penurunan harga saham di masa mendatang. Berbeda dengan Leverty \& Grace (2012) dimana tingkat percaya diri CEO yang tinggi didasarkan atas kemampuan manajerial yang baik dalam memanfaatkan sumber daya perusahaan sehingga mampu untuk meningkatkan kinerja perusahaan.

Terdapat beberapa faktor yang mempengaruhi tingkat percaya diri CEO dalam mengambil keputusan seperti usia, pendidikan dan pengalaman kerja. Menurut teori upper echelon yang dikembangkan oleh Hambrick \& Mason (1984) bahwa usia seseorang mempengaruhi seberapa cepat keputusan diambil, pendidikan sebagai dasar teori dalam pengambilan keputusan sedangkan pengalaman sebagai validasi pengetahuan yang disesuaikan dengan kondisi yang ada dilapangan. Pendidikan menjadi salah satu faktor yang cukup mendominasi dalam pengambilan keputusan seperti hasil penelitian Gupta, et al. (2018) yang menjelaskan bahwa pendidikan keuangan yang dimiliki CEO berpengaruh positif terhadap keputusan investasi perusahaan.

Usia, pendidikan dan pengalaman kerja tidak seutuhnya menjamin bahwa keputusan yang diambil CEO tidak bias. Adanya konflik kepentingan mampu untuk mempengaruhi keputusan yang diambil oleh CEO. Ketika keputusan yang 
diambil tidak sesuai dengan ekspektasi dan mampu untuk menurunkan kinerja perusahaan, maka ada peluang bagi CEO untuk menunda informasi. Penundaan informasi negatif yang dilakukan CEO untuk menjaga kredibilitas, tingkat kompensasi, kinerja dan citra sebagai pemimpin manajemen. Penundaan informasi negatif perusahaan yang lama oleh CEO akan berisiko menurunkan harga saham di masa depan. Hal tersebut sesuai dengan model gelembung stokastik Blanchard \& Watson, (1982) dimana asimetri informasi yang terpublikasi secara bersama-sama akan menyebabkan penurunan harga saham hingga return yang diberikan bernilai negatif. Dapat disimpulkan bahwa tingkat percaya diri CEO dapat mempengaruhi perilaku untuk menunda informasi negatif ketika keputusan yang diambil baik investasi atau keputusan lainnya tidak sesuai dengan yang diharapkan, sehingga berisiko menurunkan harga saham di masa depan. Adanya pengaruh tingkat percaya diri CEO terhadap efisiensi investasi dan risiko penurunan harga saham di masa depan serta adanya pengaruh efisiensi investasi terhadap risiko penurunan harga saham memberikan ketertarikan bagi peneliti untuk menguji hubungan langsung dan tidak langsung.

Sektor manufaktur dipilih sebagai objek penelitian dikarenakan adanya hubungan erat dengan R\&D yang membutuhkan dana investasi yang cukup besar sehingga dapat menggambarkan bagimana perilaku CEO dalam mengambil keputusan investasi. Tujuan penelitian ini untuk menguji bagaimana hubungan langsung antara tingkat percaya diri CEO dengan risiko penurunan harga saham di masa depan dan hubungan tidak langsung dengan efisiensi sebagai variabel mediasi. Hasil penelitian ini berkontribusi untuk menjelaskan hubungan antara tingkat percaya diri CEO, efisiensi investasi dan risiko penurunan harga saham di masa depan.

Karakteristik digunakan sebagai tolak ukur tingkat percaya diri CEO didasarkan atas teori upper echelon Hambrick \& Mason, (1984) dimana umur, pendidikan dan pengalaman dapat mempengaruhi keputusan. Sejalan dengan pendapat Gerayli, et al. (2021) bahwa karakteristik kepribadian manajer menjadi salah satu faktor dalam mengambil keputusan. Pengalokasian modal untuk investasi merupakan salah satu keputusan CEO dan tingkat efisiensi investasi menggambarkan tingkat kesenjangan antara nilai yang diperhitungkan dengan hasil investasi yang diterima. Oleh sebab itu peneliti tertarik untuk menguji pengaruh tingkat percaya diri CEO dengan efisiensi investasi. Huang, et al. (2011), Wang, et al. (2016) dan He, et al. (2019) telah meneliti pengaruh tingkat percaya diri CEO terhadap efisiensi investasi yang hasilnya menunjukan adanya pengaruh positif tingkat percaya diri CEO terhadap tingginya investasi. Atas penelitian tersebut membuktikan bahwa semakin tinggi tingkat percaya diri CEO makakeputusan nilai investasi akan meningkat.

CEO akan berusaha secara maksimal untuk menunjukan kemampuannya dengan karakteristik yang dimiliki. Seperti yang dijelaskan oleh Gervais, et al. (2011) bahwa manajer yang terlalu percaya diri melakukan lebih banyak upaya untuk mengumpulkan informasi yang menciptakan nilai bagi kebijakan investasi perusahaan. Hal ini dapat disimpulkan bahwa semakin tinggi tingkat percaya diri CEO maka semakin banyak informasi yang dikumpulkan untuk menghasilkan keputusan investasi yang efisien. Oleh sebab itu diperkirakan tingkat percaya diri CEO yang berlebihan berpengaruh positif terhadap efisiensi investasi. 
$\mathrm{H}_{1}$ : Tingkat percaya diri CEO yang berlebihan berpengaruh positif terhadap efisiensi investasi.

Semakin banyak informasi yang dikumpulkan oleh CEO semakin besar peluang keputusan yang dihasilkan bias. Hal ini didasarkan atas terbatasnya kemampuan individual dalam mengolah informasi (bounded rationality) dan dapat menghasilkan keputusan yang irasional. Yang, et al. (2011) berpendapat bahwa terlalu percaya diri merupakan salah satu perilaku irasional. Berdasarkan teori psikologi, bahwa seseorang yang terlalu percaya diri akan meyakini bahwa dirinya memiliki kemampuan yang memumpuni dan lebih baik dari individu lain (Galasso \& Simcoe, 2011).

Keputusan investasi yang bias memiliki peluang untuk menurunkan kinerja CEO. Ketika keputusan investasi yang dihasilkan benar-benar menurunkan kinerja CEO, maka CEO akan berusahaa mencari cara untuk menuntupi kekurangan dari kinerjanya salah satunya adalah menunda informasi. Penundaan informasi akan menghasilkan asimetri informasi dengan pemegang kepentingan sehingga akan menimbulkan konflik agensi (Jensen \& Meckling, 1976). Sejalan dengan pendapat Xiaorong, et al. (2017) dimana penundaan informasi oleh manager didasarkan atas agensi konflik, manajer akan menunda informasi buruk sampai titik tertentu untuk menjaga tingkat kepercayaan publik, namun ketika informasi buruk terpublikasi secara keseluruhan akan menurunkan harga saham perusahaan.

Informasi buruk yang ditunda terlalu lama akan memberikan dampak negatif bagi nilai perusahaan ketika terpublikasi secara bersamaan, seperti model gelembung stokastik (Blanchard \& Watson, 1982) dimana asimetri informasi yang terpublikasi secara bersama-sama akan menyebabkan penurunan harga saham hingga return yang diberikan bernilai negatif. Beberapa peneliti terdahulu terlah menguji pengaruh tingkat percaya diri CEO terhadap risiko penurunan harga saham masa depan, seperti hasil penelitan Kim, et al. (2016), Lee, et al. (2018), Liang, et al. (2019), dan Mamun, et al. (2020) hasilnya menunjukan adanya pengaruh positif. Oleh sebab itu pada penelitian ini diperkirakan semakin tinggi tingkat percaya diri CEO semakin rendah risiko penurunan harga saham di masa depan.

$\mathrm{H}_{2}$ : Tingkat percaya diri CEO yang berlebihan berpengaruh negatif terhadap risiko penurunan harga saham perusahaan di masa depan.

Menurut Habib \& Hasan (2017), Khurana, et al. (2018), Li \& Guo (2020) efisiensi investasi berpengaruh positif terhadap risiko penurunan harga saham di masa depan yang artinya semakin tidak efisien investasi yang dipilih maka semakin tinggi risiko penurunan harga saham. Investor akan merespon positif ketika investasi yang dipilih manajemen mampu untuk meningkatkan nilai perusahaan. Namun respon yang berbeda ketika investasi yang dipilih memberikan penurunan nilai perusahaan. Atas dasar teori upper echelon yang dikembangkan oleh Hambrick \& Mason (1984) dimana manajemen sebagai kunci dalam mengambil seluruh keputusan tidak terkecuali strategi investasi. Apabila strategi investasi yang dipilih salah maka ada kemungkinan untuk menunda informasi yang akan mengakibatkan asimetri informasi. Oleh sebab itu dalam penelitian ini diperkirakan semakin efisien investasi maka akan menurunkan risiko penurunan harga saham di masa depan. 
$\mathrm{H}_{3}$ : Efisiensi investasi berpengaruh negatif terhadap risiko penurunan harga saham perusahaan di masa depan.

Atas dasar teori upper echelon Hambrick \& Mason, (1984) dan pendapat Gerayli, et al. (2021) dimana tingkat percaya diri CEO berpengaruh terhadap pengambilan keputusan tidak terekecuali strategi investasi yang akan diukur tingkat efisiensinya dan ketika hasilnya buruk maka akan memunculkan penundaan informasi. Penundaan informasi akan menimbulkan asimetri sehingga dapat menimbulkan adanya konflik antar pemegang kepentingan (Jensen \& Meckling, 1976). Lamanya penundaan informasi diperkirakan akan mempengaruhi nilai saham perusahaan di masa depan ketika terpublikasi secara bersamaan. Xiaorong, et al. (2017) menjelaskan bahwa manajer yang memilih untuk menunda informasi buruk untuk menjaga tingkat kepercayaan publik akan mengalami penurunan harga saham dimasa depan.

Hasil penelitian Huang, et al. (2011), Wang, et al. (2016) dan He, et al. (2019) menjelaskan bahwa tingkat percaya diri CEO berpengaruh terhadap efisiensi investasi. Penelitian lainnya milik Kim, et al. (2016), Lee, et al. (2018), Liang, et al. (2019), dan Mamun, et al. (2020) menjelaskan bahwa tingkat percaya diri CEO berpengaruh positif terhadap risiko penurunan harga saham di masa depan. Efisinsi investasi juga berpengaruh positif terhadap risiko penurunan harga saham hal tersebut telah dibuktikan oleh Habib \& Hasan (2017), Khurana, et al. (2018), Li \& Guo (2020). Atas dasar penelitian terdahulu dan pendapat Hair Jr, et al. (2016) yang menjalaskan bahwa dengan adanya variabel mediasi dapat memperjelas hubungan variabel dependen dan variabel dipenden, maka dalam penelitian ini menggunakan efisiensi investasi sebagai variabel mediasi.

$\mathrm{H}_{4}$ : Efisiensi investasi memediasi pengaruh tingkat percaya diri CEO yang berlebihan terhadap risiko penurunan harga saham perusahaan di masa depan.

Berdasarkan penjelasan latar belakang dan hipotesis di atas, peneliti tertarik untuk menguji pengaruh tingkat percaya diri CEO terhadap risiko penurunan harga saham di masa depan dengan efisiensi investasi sebagai variabel mediasi sesuai dengan kerangka penelitian pada Gambar 1.

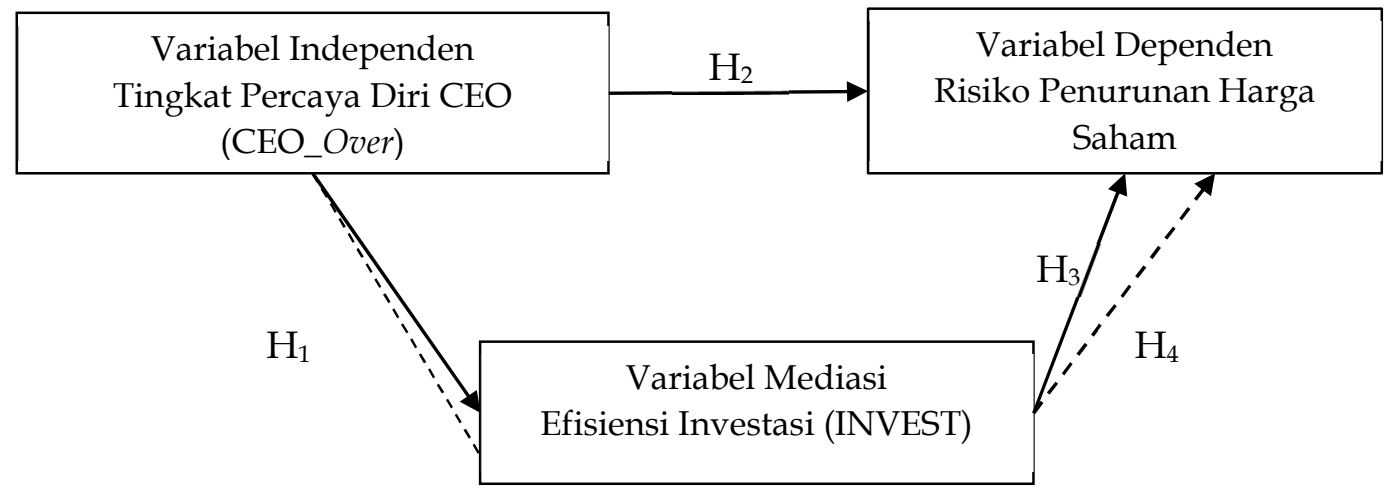

Keterangan:

- Pengaruh Langsung

-..-- Pengaruh Tidak Langsung

Sumber: Data Penelitian, 2021

Gambar 1. Kerangka Penelitian 


\section{METODE PENELITIAN}

Jenis penelitian ini adalah kuantitatif. Data yang dibutuhkan dalam penelitian ini adalah saham mingguan dan laporan tahunan perusahaan. Data saham mingguan digunakan untuk menghitung risiko penurunan harga saham. Laporan tahunan perusahaan digunakan untuk menghitung tingkat percaya diri CEO dan efisiensi investasi. Sumber data diperoleh dari www.finance.yahoo.com dan www.idnfinancials.com. Populasi penelitian ini adalah perusahaan sektor manufaktur yang terdaftar di Bursa Efek Indonesia (BEI) periode 2008-2019. Teknik pengambilan sampel penelitian adalah purposive sampling dengan beberapa kriteria yang telah ditentukan sebagai berikut.

\section{Tabel 1. Kriteria Sampel}

\section{Populasi}

Seluruh perusahaan manufaktur yang terdaftar di Bursa Efek Indonesia periode 2008-2019

189 Perusahaan

Tidak Memenuhi Kriteria Sampel

Jumlah perusahaan delisting dari Bursa Efek Indonesia periode 2008-2019

9 Perusahaan

Tidak memiliki laporan tahunan periode 2008-2019

67 Perusahaan

Tidak memiliki histori harga saham mingguan periode 1

Januari 2011 - 31 Desember 2019

15 Perusahaan

Jumlah Perusahaan Sampel

98 Perusahaan

Sumber: Data Penelitian, 2021

Berdasarkan kriteria sampel penelitian pada Tabel 1, terdapat kriteria laporan tahunan periode 2008-2009 yang akan digunakan untuk menghitung efisiensi investasi yang memerlukan data pendapatan dua tahun yang lalu (t-2). Total perusahaan yang digunakan sebagai sampel penelitian adalah 98 perusahaan manufaktur dengan kurun waktu 9 tahun dengan demikian total sampel penelitian adalah 882 data.

Chen, et al. (2001) menggunakan model persamaan pasar saham untuk menghitung bobot sebagai dasar perhitungan negative conditional returns skewness (NSKEW) sebagai indeks pengukuran risiko penurunan harga saham. Berikut adalah model persamaan pasar.

$r_{j, \tau}=\alpha_{j}+\beta_{1 j}, r_{j, \tau-2}+\beta_{2 j}, r_{j, \tau-1}+\beta_{3 j}, r_{j}+\beta_{4 j}, r_{j, \tau+1}+\beta_{5 j}, r_{j, \tau+2}+\varepsilon_{j, \tau}$

Keterangan :

$\mathrm{r}_{j, t} \quad$ : Harga saham penutupan mingguan

$\mathrm{a}_{i} \quad$ : Koefisien persamaan

$\mathrm{r}_{j} \quad$ : Indeks harga saham gabungan mingguan

$\varepsilon_{j, t} \quad$ : Residual

Semakin tinggi nilai NSKEW maka semakin besar peluang risiko penurunan harga saham. Berikut model perhitungan negative conditional return skewness (NSKEW).

$$
N \text { SKE } W_{j, t}=\frac{-\left[n(n-1)^{\frac{3}{2}} \sum W_{j, w}^{3}\right]}{(n-1)(n-2)\left(\sum W_{j, w}^{2}\right)^{\frac{3}{2}}}
$$

Keterangan :

NSKEW $_{i, t}:$ Negatif skewness atas pengembalian saham 


\section{n : Jumlah sampel \\ $\sum W_{j, w}^{3} \quad:$ Jumlah bobot pengembalian saham mingguan pangkat tiga \\ $\sum W_{j, w}^{2} \quad$ : Jumlah bobot pengembalian saham mingguan pangkat dua}

Berdasarkan teori upper echelon yang dikembangkan oleh Hambrick \& Mason (1984) dimana manajemen puncak dalam mengambil keputusan dipengaruhi oleh beberapa faktor salah satunya adalah karakteristik manajemen puncak seperti umur, pendidikan, dan pengalaman. Atas dasar teori upper echelon dan hasil penelitian Liang, et al. (2019) terdapat lima karakteristik CEO yang digunakan untuk menentukan tingkat percaya diri CEO, sebagai berikut: (1) Jenis Kelamin, jika CEO perusahaan adalah laki-laki akan diberi nilai 1 dan perempuan diberi nilai 0, (2) Usia, jika umur CEO di bawah rata-rata sampel akan diberi nilai 1 dan bernilai 0 apabila melebihi nilai rata-rata sampel, (3) Pendidikan, diberi nilai 1 jika CEO telah melalui pendidikan Magister atau selebihnya, dan memiliki pendidikan Sarjana atau dibawahnya diberi nilai 0, (4) Latar Belakang Pendidikan, jika jurusan pendidikan CEO adalah ekonomi atau bisnis akan bernilai 1 dan jika jurusan pendidikan selain ekonomi atau bisnis bernilai 0, (5) Masa jabatan, jika nilai masa jabatan di bawah median sample akan diberi nilai 1 dan bernilai 0 jika masa jabatan di atas median sample.

Atas dasar lima karakteristik CEO di atas akan di hitung rata-rata tingkat percaya diri CEO dan dikategorikan menjadi dua kelompok yakni tingkat percaya diri yang berlebihan (overconfidence) dengan rata-rata diatas 0,5 dan tingkat percaya diri yang rendah (underconfidence) dengan rata-rata dibawah 0,5.

Pengukuran tingkat efisiensi investasi menggunakan model persamaan yang dikembangkan oleh McNichols \& Stubben (2008) dimana prediktabilitas atas perubahan pendapatan dapat digunakan untuk menentukan tingkat kelebihan dan kekurangan investasi dengan persamaan sebagai berikut.

$I N V_{i, t}=\gamma_{0}+\gamma_{1} N E G_{i, t-1}+\gamma_{2}$ REVGROW $_{i, t-1}+\gamma_{3} N E G^{*} \operatorname{REVGROW}_{i, t-1}+\varepsilon_{i, t}$

Keterangan:

$\mathrm{INV}_{i, t} \quad$ : Nilai aktiva tetap dibagi dengan total aktiva

yo : Konstanta

$\gamma_{1} N E G_{i, t-1} \quad$ : Apabila perubahan pendapatan tahun sebelumnya bernilai negatif akan diberi nilai 1 dan positif bernilai 0

$\gamma_{2}$ REVGROW $_{i, t-1}$ : Perubahan pendapatan tahun sebelumnya

$\varepsilon_{i, t} \quad$ : Residual

Nilai efisiensi investasi diambil dari nilai residual pada persamaan 3. Semakin kecil nilai residual dan mendekati 0 maka semakin efisien investasi yang dipilih perusahaan. Metode analisis yang digunakan adalah analisis jalur dengan model persamaan sebagai berikut.

Invest $_{\mathrm{t}}=\alpha_{0}+\alpha_{1}$ CEO_Over $_{\mathrm{t}}+\varepsilon$

NSKEW $_{\mathrm{t}+1}=\alpha_{0}+\alpha_{1}$ CEO_Over $_{\mathrm{t}}+\alpha_{2}$ Invest $_{\mathrm{t}}+\varepsilon$.

Keterangan:

Invest $t_{t} \quad$ : Efisiensi investasi tahun $t$

CEO_Over ${ }_{t}$ : Tingkat percaya diri CEO tahun $\mathrm{t}$

NSKEW $_{\mathrm{t}+1} \quad$ : Risiko penurunan harga saham tahun depan $(\mathrm{t}+1)$

$\alpha \quad$ : Konstanta 
$\varepsilon$ : Residual

Sobel test digunakan untuk menguji variabel mediasi._Tahap awal menghitung sobel test adalah dengan mengetahui nilai standar error dengan rumus sebagai berikut. $s a b=\sqrt{b^{2} s a^{2}+a^{2} s b^{2}+s a^{2} s b^{2}}$

Setelah itu menghitung $\mathrm{t}$ hitung untuk menentukan signifikasi apakah memediasi atau tidak dengan rumus sebagai berikut. $t=\frac{a b}{s a b}$

Apabila nilai $t$ hitung lebih besar dibandingkan dengan $t$ Tabel maka hasilnya adalah signifikan dan memediasi.

\section{HASIL DAN PEMBAHASAN}

Hasil analisis deskriptif dapat diperhatikan pada Tabel 2, dimana total data penelitian yang memenuhi uji normalitas adalah 350 data dari 882 data penelitian. Pada Tabel 2, nilai maksimum tingkat percaya diri CEO (CEO_Over) adalah 1 dengan nilai minimum adalah 0 dimana nilai rata-rata lebih besar dibandingkan standar deviasi $(0,614>0,488)$ sehingga data bersifat homogen. Nilai maksimum efisiensi investasi (Invest) adalh 0,447 dengan nilai minimum -0,461 dimana nilai rata-rata lebih kecil dibandingkan standar deviasi sehingga data bersifat heterogen. Nilai maksimum negative conditional returns skewness (NSKEW) adalah 0,954 dengan nilai minimun -0,596 dimana nilai rata-rata lebih kecil dibandingkan standar deviasi sehingga data bersifat heterogen.

Tabel 2. Statistik Desktiptif

\begin{tabular}{llrrrc}
\hline Variabel & $\mathrm{N}$ & \multicolumn{1}{c}{ Min } & \multicolumn{1}{c}{ Max } & \multicolumn{1}{c}{ Mean } & Std. Deviation \\
\hline CEO_Over & 350 & 0,000 & 1,000 & 0,614 & 0,487 \\
Invest & 350 & $-0,461$ & 0,447 & 0,001 & 0,183 \\
NSKEW & 350 & $-0,596$ & 0,954 & 0,197 & 0,319 \\
\hline
\end{tabular}

Sumber: Data Penelitian, 2021

Pada Tabel 3, menunjukan nilai $\mathrm{R}^{2}$ dari dua persamaan yang digunakan dalam penelitian ini. Persamaan pertama menguji pengaruh langsung tingkat percaya diri CEO (CEO_Over) terhadap efisiensi investasi (Invest). Hasilnya menunjukkan bahwa tingkat percaya diri CEO (CEO_Over) dalam menjelaskan efisiensi investasi (Invest) sebesar 7,3 persen. Persamaan kedua menguji pengaruh langsung tingkat percaya diri CEO (CEO_Over) dan efisiensi investasi (Invest) terhadap risiko penurunan harga saham (NSKEW). Hasilnya menunjukkan bahwa tingkat percaya diri CEO (CEO_Over) dan efisiensi investasi (Invest) memiliki kemampuan 7,7 persen menjelaskan risiko penurunan harga saham (NSKEW).

Tabel 3. R Square

\begin{tabular}{lccc}
\hline Model & $\mathrm{R}$ & $\mathrm{R}$ Square & Adjusted $\mathrm{R}$ Square \\
\hline Invest & 0,270 & 0,073 & 0,070 \\
NSKEW & 0,278 & 0,077 & 0,072 \\
\hline
\end{tabular}

Sumber: Data Penelitian, 2021

Berdasarkan Tabel 4, menunjukan bahwa model persamaan yang dirumuskan dapat diterima dan secara bersamaan variabel independen 
mempengaruhi variabel dependen dengan nilai signifikan $(0,000)$ kurang dari 0,05 .

Tabel 4. Uji Statistik F

\begin{tabular}{|c|c|c|c|c|c|}
\hline Model & Sum of Squares & $d f$ & Mean Square & $\mathrm{F}$ & Sig. \\
\hline Regression & 2,735 & 2 & 1,367 & 14,494 & $0,000^{\mathrm{b}}$ \\
\hline Residual & 32,737 & 347 & 0,094 & & \\
\hline Total & 35,472 & 349 & & & \\
\hline \multicolumn{6}{|c|}{ a. Dependent Variable: NSKEW $_{\mathrm{t}+1}$} \\
\hline \multicolumn{6}{|c|}{ b. Predictors: (Constant), CEO_Over ${ }_{\mathrm{t}}$ Invest $_{\mathrm{t}}$} \\
\hline
\end{tabular}

Sumber: Data Penelitian, 2021

Berdasarkan Tabel 5, menunjukan nilai signifikan CEO_Over $(0,000)$ kurang dari 0,05 yang artinya secara signifikan positif mempengaruhi efisiensi investasi dengan demikian $\mathrm{H}_{1}$ dapat diterima. Pada hasil penelitian ini menunjukan semakin tinggi tingkat percaya diri CEO maka semakin efisien investasi perusahaan. Hasil penelitian ini sejalan dengan penelitian terdahulu miliki Huang, et al. (2011), Wang, et al. (2016), dan He, et al. (2019). Hasil penelitian ini membuktikan teori upper echelon Hambrick \& Mason, (1984) dimana tingkat percaya diri CEO yang diukur dari karakteristik seperti jenis kelamin, umur, masa jabatan, latar belakang pendidikan, dan tingkat pendidikan mampu menghasilkan keputusan yang efisien dalam mengalokasikan modal perusahaan untuk berinvestasi.

Tabel 5. Uji Statistik $\mathrm{t}$ Pengaruh Tingkat Percaya Diri CEO Terhadap Efisiensi Investsi

\begin{tabular}{|c|c|c|c|c|c|c|}
\hline \multirow{2}{*}{\multicolumn{2}{|c|}{ Model }} & \multicolumn{3}{|r|}{$\begin{array}{l}\text { Standardized } \\
\text { Coefficients }\end{array}$} & \multirow[t]{2}{*}{$\mathrm{t}$} & \multirow[t]{2}{*}{ Sig. } \\
\hline & & B & Std. Error & Beta & & \\
\hline \multirow[t]{2}{*}{1} & (Constant) & $-0,026$ & 0,007 & & $-3,630$ & 0,000 \\
\hline & CEO_Over & 0,051 & 0,010 & 0,270 & 5,239 & 0,000 \\
\hline
\end{tabular}

a Dependent Variable: Invest $t_{t}$

Sumber: Data Penelitian, 2021

Berdasarkan Tabel 6, menunjukan nilai signifikan CEO_Over $(0,003)$ kurang dari 0,05 yang artinya secara signifikan negatif mempengaruhi risiko penurunan harga saham di masa depan dan menerima $\mathrm{H}_{2}$. Hasil penelitian ini menunjukan bahwa semakin tinggi tingkat percaya diri CEO maka semakin rendah risiko penurunan harga saham di masa depan. Hasil penelitian ini tidak sejalan dengan penelitian milik Kim, et al. (2016), Lee, et al. (2018), Liang, et al. (2019), dan Mamun, et al. (2020) yang menunjukan tingkat percaya diri CEO berpengaruh positif terhadap risiko penurunan harga saham di masa depan. Atas dasar penelitian ini menunjukan bahwa kinerja CEO saat ini didasarkan atas kemampuan yang dimiliki dan tidak adanya perilaku penundaan informasi yang dapat menurunkan harga saham di masa depan. Hal tersebut membuktikan bahwa tidak adanyan konflik agensi yang ditimbulkan atas tingkat percaya diri CEO yang dapat mengambil keputusan secara bias dan dapat menurunkan harga saham di masa depan. 
Tabel 6. Uji Statistik $t$ Pengaruh Tingkat Percaya Diri CEO dan Efisiensi Investasi Terhadap Risiko Penurunan Harga Saham di Masa Depan

\begin{tabular}{|c|c|c|c|c|c|}
\hline \multirow{2}{*}{ Model } & \multicolumn{2}{|c|}{ Unstandardized Coefficients } & \multirow{2}{*}{$\begin{array}{c}\begin{array}{c}\text { Standardized } \\
\text { Coefficients }\end{array} \\
\text { Beta }\end{array}$} & \multirow[t]{2}{*}{$t$} & \multirow{2}{*}{ Sig. } \\
\hline & B & Std. Error & & & \\
\hline (Constant) & 0,260 & 0,026 & & 9,831 & 0,000 \\
\hline Invest $_{t}$ & 0,400 & 0,090 & 0,230 & 4,457 & 0,000 \\
\hline CEO_Overt & $-0,103$ & 0,034 & $-0,157$ & $-3,040$ & 0,003 \\
\hline
\end{tabular}

a. Dependent Variable: NSKEW $_{\mathrm{t}+1}$

Sumber: Data Penelitian, 2021

Berdasarkan Tabel 6, nilai signifikan Invest $t_{t}(0,000)$ kurang dari 0,05 yang artinya secara signifikan positif berpengaruh terhadap risiko penurunan harga saham di masa depan dan tidak sejalan dengan $\mathrm{H}_{3}$. Hasil penelitian ini menunjukan bahwa semakin tidak efisien alokasi investasi maka semakin tinggi risiko penurunan harga saham di masa depan. Hasil penelitian ini sejalan dengan hasil penelitian Habib \& Hasan (2017), Pereira, et al. (2018), serta Li \& Guo (2020) yang menunjukan bahwa efisiensi investasi berpengaruh positif terhadap risiko penurunan harga saham. Atas dasar penelitian ini menunjukan bahwa jika ada penundaan informasi atas ketidak efisiensian investasi seperti investasi berlebihan atau rendahnya investasi ketika diinformasikan di masa yang akan datang akan direspon negatif oleh investor sehingga beresiko untuk menurunkan harga saham perusahaan.

Tabel 7. Sobel Test

\begin{tabular}{ll}
\hline Pengaruh langsung CEO_Over ke NSKEW & $-0,103$ \\
Pengaruh tidak langsung CEO_Over ke Invest ke NSEW & 0,020 \\
Standar Error & 0,006 \\
Uji t mediasi & 3,320 \\
\hline
\end{tabular}

Berdasarkan perhitungan sobel test pada Tabel 7, menunjukan nilai t hitung $(3,320)$ lebih besar dibandingkan $t$ Tabel 1,967 yang artinya efisiensi investasi memediasi pengaruh tingkat percaya diri CEO terhadap risiko penurunan harga saham di masa depan dan menerima $\mathrm{H}_{4}$. Atas dasar penelitian ini menunjukan bahwa tingkat percaya diri CEO dapat mempengaruhi risiko penurunan harga di masa depan melalui efisiensi investasi.

\section{SIMPULAN}

Hasil penelitian ini menunjukan bahwa tingkat percaya diri CEO berpengaruh positif terhadap efisiensi investasi. Tingkat percaya diri CEO berpengaruh negatif terhadap risiko penurunan harga saham di masa depan. Efisiensi investasi berpengaruh positif terhadap risiko penurunan harga saham di masa depan. Hasil penelitian ini membuktikan bahwa efisiensi investasi mampu untuk memediasi pengaruh tingkat percaya diri CEO terhadap risiko penurunan harga saham di masa depan.

Secara generalisasi penelitian ini tidak menggambarkan secara utuh bagaimana pengaruh tingkat percaya diri CEO terhadap risiko penurunan harga saham melalui efisiensi investasi sebagai mediasi sebab sampel penelitian yang 
digunakan hanya merujuk pada satu sektor yakni manufaktur. Diperlukan pengujian lebih lanjut dengan menggunakan seluruh sektor industri sebagai objek penelitian. Selain perluasan objek penelitian, diperlukan pengukuran alternatif untuk mengukur tingkat percaya diri CEO, efisiensi investasi dan risiko penurunan harga saham sebagai pengujian robustness guna meningkatkan validitas pengujian.

\section{REFERENSI}

Blanchard, O. J., dan Watson, M. W. (1982). Bubbles, Rational Expectations and Financial Markets. National Bureau of Economic Research. Doi: 10.3386/w0945

Chen, J., Hong, H., dan Stein, J. C. (2001). Forecasting Crashes: Trading Volume, Past Returns, and Conditional Skewness in Stock Prices. Journal of Financial Economics, 61(3), 345-381. Doi: 10.1016/S0304-405X(01)00066-6

Cheng, M., Dhaliwal, D., dan Zhang, Y. (2013). Does Investment Efficiency Improve After the Disclosure of Material Weaknesses in Internal Control Over Financial Reporting? Journal of Accounting and Economics, 56(1), 1-18.

Galasso, A., dan Simcoe, T. S. (2011). CEO Overconfidence and Innovation. Management Science, 57(8). Doi: 10.1287/mnsc.1110.1374

Gerayli, M. S., Abdoli, M., Valiyan, H., dan Damavandi, A. (2021). Managerial Overconfidence and Internal Control Weakness: Evidence from Iranian Firms. Accounting Research Journal, 34(5), 475-487. Doi: 10.1108/ARJ-022020-0043

Gervais, S., Heaton, J. B., dan Odean, T. (2011). Overconfidence, Compensation Contract, and Capital Budgeting. The Journal of Finance, 55(5), 1735-1777.

Gomariz, C. M. F., dan Ballesta, S. J. P. (2014). Financial Reporting Quality, Debt Maturity, and Investment Efficiency. Journal of Banking \& Finance, 40(1), 494-506.

Gupta, G., Mahakud, J., dan Debata, B. (2018). Impact of CEO's Characteristics on Investment Decisions of Indian Listed Firms: Does Crisis Make Any Difference? Cogent Economics \& Finance, 6(1). Doi: 10.1080/23322039.2018.1439258

Habib, A., dan Hasan, M. M. (2017). Managerial Ability, Investment Efficiency and Stock Price Crash Risk. Research in International Business and Finance, 42, 262274. Doi: 10.1016/j.ribaf.2017.07.048

Hair Jr, J. F., M., H. G. T., Ringle, C. M., dan Sarstedt, M. (2016). A Primer on PArtial Least Squares Structural Equation Modeling (PLS-SEM): Sage Publications.

Hambrick, D. C., dan Mason, P. A. (1984). Upper Echelons: The Organization as Reflection of Its Top Managers. Academy of Management Review, 9(2), 193206. Doi: $10.5465 / a m r .1984 .4277628$

He, Y., Chen, C., dan Hu, Y. (2019). Managerial Overconfidence, Internal Financing and Investment Efficiency: Evidence from China. Research in International Business and Finance, 47, 501-510. Doi: 10.1016/j.ribaf.2018.09.010

Hirshleifer, D., Low, A., dan Teoh, S. H. (2012). Are Overconfident CEOs Better Innovators? The Journal of Finance, 67(4), 1457-1498. Doi: 10.1111/j.15406261.2012.01753.x 
Huang, W., Jiang, F., Liu, Z., dan zhang, M. (2011). Agency Cost, Top Executives' Overconfidence, and Investment Cash Flow Sensitivity - Evidence from Listed Companies in China. Pacific-Basin Finance Journal, 19(3), 261-277. Doi: 10.1016/j.pacfin.2010.12.001

Hur, K. S., Kim, D. H., dan Cheung, J. H. (2019). Managerial Overconfidence and Cost Behavior of R\&D Expenditures. Sustainability, 11(18). Doi: 10.3390/su11184878

Jensen, M. C., dan Meckling, W. H. (1976). Theory of The Firm: Managerial Behavior, Agency Costs and Ownership Structure. Journal of Financial Economics, 3, 305-360. Doi: 10.1016/0304-405X(76)90026-X

Khurana, I. K., Moser, W. J., dan Raman, K. K. (2018). Tax Avoidence, Managerial Ability, and Investment Efficiency. A Journal of Accounting, Finance and Business Studies, 54(4). Doi: 10.1111/abac.12142

Khurana, I. K., Pereira, R., dan Zhang, E. X. (2018). Is Real Earnings Smoothing Harmful? Evidence from Firm-Spesific Stock Price Crash Risk. Contemporary Accounting Research, 35(1), 558-587. Doi: 10.1111/19113846.12353

Kim, J. B., Wang, W., dan Zhang, L. (2016). CEO Overconfidence and Stock Price Crash Risk. Contemporary Accounting Research, 33(4), 1720-1749. Doi: 10.1111/1911-3846.12217

Lee, Y. C., Lu, Y. C., dan Wang, Y. C. (2018). Corporate Social Irresponsibility, CEO Overconfidence and Stock Price Crash Risk. Applied Economics Letters. Doi: 10.1080/13504851.2018.1540835

Leverty, J. T., dan Grace, M. F. (2012). Dupes or Incompetents? An Examination of Management's Impact on Firm Distress. Journal of Risk and Insurance, 79(3), 751-783. Doi: 10.1111/j.1539-6975.2011.01443.x

Li, Q., dan Guo, M. (2020). Local Economic Performance, Political Promotion, and Stock Price Crash Risk: Evidence from China. Emerging Markets Finance and Trade. Doi: 10.1080/1540496X.2020.1809373

Liang, Q., Ling, L., Tang, J., Zeng, H., dan Zhuang, M. (2019). Managerial overconfidence, firm transparency, and stock price crash risk: Evidence from an emerging market. China Finance Review International, 10(3), 271-296. Doi: 10.1108/cfri-01-2019-0007

Mamun, M. A., Balachandran, B., dan Duong, H. N. (2020). Powerful CEOs and Stock Price Crash Risk. Journal of Corporate Finance, 62. Doi: 10.1016/j.jcorpfin.2020.101582

McNichols, M. F., dan Stubben, S. R. (2008). Does Earnings Management Affect Firms' Investment Decisions? The Accounting Review, 83(6), 1571-1603.

Ullah, I., Majeed, M. A., Fang, H. X., dan Khan, M. A. (2020). Female CEOs and Investment Efficiency: Evidence from an Amerging Economy. Pasific Accounting Review. Doi: 10.1108/PAR-08-2019-0099

Wang, Y., Chen, C. R., Chen, L., dan Huang, Y. S. (2016). Overinvestment, Inflation Uncertainty, and Managerial Overconfidence: Firm Level Analysis of Chinese Corporations. North American Journal of Economics and Finance, 38, 54-69. Doi: 10.1016/j.najef.2016.07.001 
Xiaorong, L., Shuye, W. S., dan Xue, W. (2017). Trust and Stock Price Crash Risk: Evidence from China. Journal of Banking \& Finance, 76, 74-91. Doi: 10.1016/j.jbankfin.2016.12.003

Yang, Y., Ma, Y. J., dan Zhu, X. P. (2011). Managerial Overconfidence and Firm Performance. Journal of Tianjin University of Commerce, 6, 4-23. 